\title{
Forward-Looking Disclosure and Corporate Reputation in the Middle of Pandemic as Mechanisms to Reduce Stock Return Volatility
}

\author{
Arja Sadjiarto ${ }^{1}$ Gabriella Ivana Gunawan ${ }^{1}$ Georgina Kelly Wibisono,"* \\ ${ }^{I}$ Department of Tax Accounting, Petra Christian University, Surabaya, Indonesia \\ ${ }^{*}$ Corresponding author. Email: georginakelly00@ gmail.com
}

\begin{abstract}
The main purpose of this paper is to examine whether financial forward-looking information and corporate reputation can reduce stock return volatility. The population of this study is manufacturing companies listed in the Indonesia stock exchange (IDX), as it is one of the most negatively affected sectors due to the pandemic, with 134 companies as the sample. This research uses a multiple regression model. The findings of this research validate previous research on how financial forward-looking disclosure can reduce information asymmetry, which is proxied by stock return volatility. On the other hand, corporate reputation did not show any significance in reducing stock return volatility.
\end{abstract}

Keywords: Corporate reputation, Disclosure, Forward-looking, Stock return volatility.

\section{INTRODUCTION}

Stock market is one of the key elements in Indonesia's economic growth. Stock return volatility is one of the many challenges investors must face when entering the market. The higher the information asymmetry, the stock's natural value will differ from the investors' considered shares value in the capital market [1]. Previous research has shown that disclosure may reduce information asymmetries [2]; [3]; [4].

Corporate annual reports are considered to be the most superior way of disclosing and communicating information to investors. Disclosure comes in various forms, the two of them being mandatory disclosure and voluntary disclosureIt is important to know the financial information in the financial statement to identify and reduce risks [3].

However, in today's rapidly changing economic environment, investors may find previous data insufficient. As a result, revealing future knowledge is much more critical [5]. Researchers have emphasized the importance of forward-looking information in enhancing company predictions and capital market decision-making [2]. Forward-looking information can offer value to the organization, enhancing investor and stakeholder trust [6].
Other than that, the effect of disclosure can have a variety of results depending on each corporate's reputation. Investors may view revealed facts with a positive bias if a company has a good reputation. Corporation with a higher level of transparency, integrity, and reliability is more likely to be preferred by investors, thus increasing the chances to reduce stock return volatility because it has a higher credibility [2].

This article expands on prior research into whether financial forward-looking disclosure and corporate image might reduce stock return volatility, and it is the first to do so in the midst of a pandemic. This study's sample consists of 134 companies from the manufacturing sector that are listed on the Indonesia Stock Exchange. As a result of the pandemic, the manufacturing sector has been one of the worst-affected sectors in the stock market. The findings and outcomes of this research may assist managers and corporations, since investors may gain from the corporate's financial forward-looking statement. There have been very few studies that have looked into forward-looking disclosure in developing countries. Aside from that, there is still no formal statutory framework in Indonesia for forwardlooking information. 


\section{LITERATURE REVIEW \& HYPOTHESIS DEVELOPMENT}

\subsection{Agency Theory}

Increased disclosure of forward-looking information reduces asymmetric information, which can be measured by stock volatility [7];[8]. When management and shareholders or stakeholders have different levels of access to information, this is known as "information asymmetry," according to reference [9]. Information asymmetry can be divided into two forms. Management and other insiders often have a better understanding of the company's current situation and future prospects than outside investors. When shareholders or lenders are not fully informed of a situation in which managers' operations are being carried out, moral hazard occurs.

Information asymmetries are less likely to cause a company's stock price to be volatile when they are minimized [10]. Agencies cost more when there is greater information asymmetry between management and investors. Because larger corporations tend to have higher costs due to the fact that their shareholders are spread out, larger firms try to disclose more information in order to reduce these costs [6]. On the other hand, some companies might voluntarily disclose future information without any obligatory motives other than attracting investors [11].

\subsection{Signalling Theory}

According to reference [6], signaling is a response to informational asymmetry in the capital market, where corporations have information that investors do not, and asymmetries can be addressed if the party with more information signals to others. Because it comprises knowledge about the past, present, and future, the aforementioned information will always be required.

Annual reports contain two types of information: retrospective and prospective [5]. Backward-looking information is defined as occurrences relating to past performance of a corporation and is thus free of the risk of non-fulfillment [3]. Forward-looking information, on the other hand, includes current plans and future estimates, such as earnings, revenues, and cash flow, as well as non-financial information such risks and uncertainties [12]. Future information disclosure is a voluntary disclosure that is not mandated by law but is determined by the manager's policy[5].

Information issued by companies will always cause a reaction from the market, where the information will be further analysed and categorized as a positive or negative signal [13]. Both categories will then affect the movement of the stock price of the company itself through changes in the trading volume.

\subsection{Stock Return Volatility}

Stock volatility signifies the pace at which stock prices increase or decrease over a particular period [14]. A high level of volatility gives space for traders to benefit from the difference from the initial price with the final price, however with a high return comes a high risk as well. Meanwhile, a low level of volatility means the price movements of a stock is shallow, thus making investors result in holding shares in a longer run to make profit [15].

Certain investors prefer stocks with a high level of volatility, since the chances of gaining a capital gain is higher [13]. However, high level of volatility is potentially undesirable as the higher it is, the riskier it will be for investors, thus resulting in a lower confidence level when investing in the capital market [10]. As a gauge of the risk and uncertainty investors face when making financial decisions, volatility, no matter how high or low it is, is essential to the smooth operation of financial markets [16].

\subsection{Forward-Looking Disclosure}

Companies' forward-looking disclosure policies have been found to be conservative in previous research [2] because disclosing this information is expensive. Forward-looking disclosure includes risks and opportunities, such as those coming from significant trends, management's plans, and crucial success factors, as well as comparisons of actual company performance to previously stated opportunities, risks, and management's plans [6].

Forward-looking disclosure has both supporters and detractors. The current economic climate is too volatile to rely just on data from the past [2]. The lack of forward-looking information could lead to investors using erroneous information in their predictions [3]. In this regard, a forecast could help users better comprehend the company's management's views and plans [6]. Forward-looking information in annual reports also helps the stock market predict future profit changes [12]. Shareholders and firms benefit from forward-looking disclosure because it minimizes the information asymmetry between the two parties.

Researchers, on the other hand, feel that it is impossible to effectively anticipate the future because of the inherent uncertainty [4]. The likelihood of a lawsuit being filed against a forecaster who was unable to accurately predict the future would grow, which could boost the expense of litigation [6];[4]. Another reason for avoiding releasing such data is competition, as the released information is of interest to investors as well as competitors [3]. An increase in proprietary expenses may have an impact on a company's ability to compete in its market [17]. When it comes to disclosing potential 
data, organizations need to consider both the advantages and risks of doing so [3].

\subsection{Corporate Reputation}

This study builds on earlier research by comparing the forward-looking information released by companies with a good reputation versus companies with a bad reputation, assuming that a firm with a good reputation can reduce volatility [2]. Studies in behavioural finance find that individual investors might be positively affected by corporate reputation.

[18] proposes that investors' primary purpose is to maximize their returns. All stock market investors have an impact on the price of a stock. The upshot is that regardless of whether an investor views business reputation as a factor in their own decision-making, they will presume that reputation influences the decisions of other investors. Higher corporate reputation is thought to indicate that investors can expect to earn in the long run by purchasing their company's stock [19].

Previous research shows that corporate reputation has different types of measurements and approaches. It is possible to describe corporate reputation as a collective view of previous activities and expectations about future actions of the organization. Corporate reputation may influence organizational effectiveness, according to some research, while others contend the inverse is true [20].

\subsection{Hypothesis}

This study extends earlier research on voluntary disclosure by looking at the link between financial forward-looking information and stock return volatility during a pandemic [2]. For investors, financial forwardlooking information is considered more reliable and precise than non-financial information. There are many benefits to publishing data that is forward-looking, such as reducing a gap in knowledge and delivering highquality information [3]. In light of the foregoing debate, the following ideas were proposed:

$\mathrm{H}_{1}$ : The disclosure of financial forecasts reduces the volatility of stock returns.

A company's reputation is an important factor in establishing a mutually beneficial relationship with its stakeholders [21]. Even in developed countries, studies on the impact of a company's reputation on stock volatility are still rare. Hypotheses based on this discussion include the following:

$\mathrm{H}_{2}$ : Corporates with a higher reputation has a greater effect in the reduction of stock return volatility

\section{METHOD}

\subsection{Sample}

The companies included in this study were all listed on the Indonesia Stock Exchange, making up the majority of the study's participants. For this study, 134 companies with a complete annual report for the 2020 reporting year were selected.

\subsection{Variable Measurement and Definition}

\subsubsection{Dependent Variable}

The dependent variable of this research is stock return volatility. Annual reports were released by the end of the third month of each year. Therefore, to calculate stock return volatility (STDRET), data concerning the daily prices were collected from Yahoo Finance, with an observation period of three months starting from April. According to previous research by [10]; [22]; [2], stock return volatility was calculated by using the natural log of one plus the standard deviation of daily stock return.

\subsubsection{Independent Variable}

Annual reports were used to quantify forwardlooking disclosure as the first independent variable in this study. Financial forward-looking information in annual reports was tallied using a content analysis technique. It was done by hand for each piece of data. As in prior studies [2];[4];[6], the phrase was utilized as a unit of measurement. Key terms were used to determine the amount of financial forward-looking information, as shown in Table 1 after a study by Hussainey et al [2003]. Another variable in this study was a company's reputation, which was assessed by counting the number of awards stated in each company's annual report.

\subsubsection{Control Variable}

Furthermore, several control variables were used in this study to examine its influence on reducing stock return volatility. Firstly, leverage (LEV) was measured by the calculating the ratio of total debt to total assets and was used as an indicator of a firm's risk [10].

Secondly, firm size (SIZE) was measured by calculating the market value. Previous studies suggest that smaller firms tend to experience a higher level of volatility [10]. The larger the firm size, the higher the diversification of activities, thus larger companies tend to have more public information and can reduce price volatility [15].

To round things out, prior studies have found a link between trading volume (TVOL) and stock return 
volatility [10]; [15]. By dividing the average monthly trading volume by the typical number of outstanding shares, we were able to calculate trading volume. Finally, the return on equity ratio was utilized to assess the overall performance of the company (PERF). Table 2 lists all of the variables that were considered during the research process. According to Bravo [2016], the following double regression model was employed:

\section{STDRET $t+1=\alpha+\beta 1$ FFLDISC $t+\beta 2$ REPt $+\beta 3$ LEV $t+\beta 4$} SIZEt $+\beta 5$ TVOLt $+\beta 6$ PERFt $+\epsilon$

\section{RESULTS AND DISCUSSION}

The descriptive analysis for each variable is shown in Table 3. Result shows a diversity in disclosure strategies, as the minimum amount of forward-looking information counts as zero and the maximum being 37 . On average, corporates tend to disclose around 14 sentences containing financial forward-looking information. Other than that, during 2020, some companies received zero awards, some received more with the highest being 38 .

Normality, autocorrelation, multicollinearity and heteroscedasticity tests are necessary for an unbiased regression model. Results of the traditional assumption test are shown in Table 4. Due to the contrasting size of the data, a lot of the data was identified as an outlier. Instead of deleting the outliers, data transformation using the natural $\log$ of one for each variable was used.

Normality was examined with the One-Sample Kolmogorov-Smirnov method. The outcome was 0,095, which is above 0,05 , therefore it can be said that the data is distributed normally.

In the absence of multicollinearity, all variables have tolerance values greater than 0.10 and Variance Inflation Factor (VIF) values lower than 10. The results from the autocorrelation test can be seen by the DurbinWatson value. Compared to the $\mathrm{dL}$ value as

Table 1. List of keywords

List of Keywords: Financial Forward-Looking Disclosure

Accelerate, anticipate, await, coming year(s), coming month(s), confidence, confident, convince, estimate, eventual, expect, forecast, forthcoming, hope, intend, intention, likely, unlikely, look ahead, look forward, next, novel, optimistic, outlook, planned, planning, predict, prospect, remain, renew, scope for, scope to, shall, shortly, should, soon, will, well placed, well positioned, years ahead

Table 2. Definition and measurements of variable

\begin{tabular}{|c|c|c|}
\hline Variable & \multicolumn{1}{|c|}{ Description } & \multicolumn{1}{|c|}{ Measurement } \\
\hline STDRET & Stock return volatility & $\begin{array}{l}\text { One plus the log of } \\
\text { standard deviation of } \\
\text { daily stock returns }\end{array}$ \\
\hline FFLDIS & Financial forward-Number of sentences \\
\hline
\end{tabular}

\begin{tabular}{|c|l|l|}
\hline & looking disclosure & $\begin{array}{l}\text { with financial } \\
\text { forward-looking } \\
\text { information }\end{array}$ \\
\hline REP & Corporate reputation & $\begin{array}{l}\text { Number of awards } \\
\text { received }\end{array}$ \\
\hline LEV & Financial leverage & $\begin{array}{l}\text { Total debt/total } \\
\text { assets }\end{array}$ \\
\hline SIZE & Firm size & Market value \\
\hline PERF & Firm performance & Return on equity \\
\hline TVOL & Trading volume & $\begin{array}{l}\text { Average monthly } \\
\text { volume/average } \\
\text { shares outstanding }\end{array}$ \\
\hline
\end{tabular}

Table 3. Descriptive analysis

\begin{tabular}{|c|c|c|c|}
\hline Variable & $\mathrm{N}$ & Minimum & Maximum \\
\hline STDRET 1 & 34 & 0.00000 & 0.10695 \\
\hline FFLDIS & & 0 & 37 \\
\hline REP & & 0 & 38 \\
\hline LEV & & 0.002 & 5.168 \\
\hline SIZE & & 30408787200 & 280402504704000 \\
\hline PERF & & 0.00000 & 0.02412 \\
\hline TVOL & & -4.113 & 1.536 \\
\hline Variable & $\mathrm{N}$ & Mean & Std. Deviation \\
\hline STDRET & 134 & 0.0351605 & 0.02078415 \\
\hline FFLDIS & & 14.71 & 9.374 \\
\hline REP & & 2.96 & 4.916 \\
\hline LEV & & 0.49292 & 0.493446 \\
\hline SIZE & & $\begin{array}{l}1508014094 \\
3751.89\end{array}$ & $\begin{array}{l}41884323792656 . \\
766\end{array}$ \\
\hline PERF & & 0.0013451 & 0.00325204 \\
\hline TVOL & & 0.05478 & 0.495054 \\
\hline
\end{tabular}

Source : Author's Processed Results on SPSS Output

Table 4. Classic assumption test

\begin{tabular}{|c|c|c|c|c|}
\hline & Normality & \multicolumn{2}{|c|}{ Multicollinearity } & Autocorrelation \\
\hline & $\begin{array}{l}\text { Kolmogorov- } \\
\text { Smirnov }\end{array}$ & $\begin{array}{l}\text { Toleran } \\
\text { ce }\end{array}$ & VIF & $\begin{array}{l}\text { Durbin- } \\
\text { Watson }\end{array}$ \\
\hline FFLDIS & \multirow{6}{*}{$\begin{array}{c}\text { Asymp. Sig. } \\
\text { [2-tailed] } \\
0.094\end{array}$} & 14.71 & 1.263 & \multirow{6}{*}{2,103} \\
\hline REP & & 2.96 & 1.548 & \\
\hline LEV & & $\begin{array}{c}0.4929 \\
2\end{array}$ & 1.078 & \\
\hline SIZE & & $\begin{array}{c}150801 \\
409437 \\
51.89\end{array}$ & 1.052 & \\
\hline PERF & & $\begin{array}{c}0.0013 \\
451\end{array}$ & 1.031 & \\
\hline TVOL & & $\begin{array}{c}0.0547 \\
8\end{array}$ & 1.546 & \\
\hline
\end{tabular}

Source : Author's Processed Results on SPSS Output

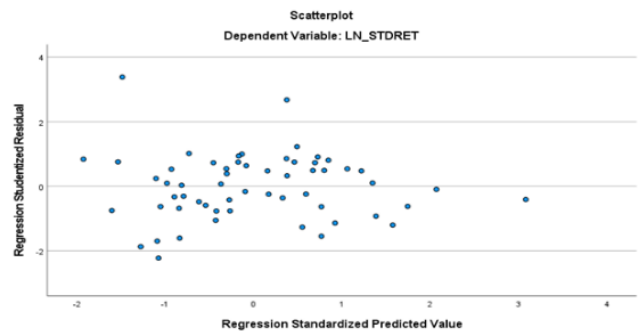

Figure 1 Heteroscedasticity test 
1.6255 and $\mathrm{dU}$ value as 1.8122 acquired from the D$\mathrm{W}$ table, all of the data are free from any autocorrelation as the $\mathrm{D}-\mathrm{W}$ value is between $\mathrm{dU}$ and $4-\mathrm{dU}$.

Lastly, the results from the heteroscedasticity test can be seen in Figure 1, where the points spread randomly, above and below 0 on the $\mathrm{Y}$ axis, which means that the regression model does not contain any heteroscedasticity.

In Table 5, with $95 \%$ as the confidence level, $\alpha=$ $5 \%$, df1 (number of variables) $=6$ and df 2 (n-6) or 134 $6=128$, the results obtained from the F table are 2.17, with $\mathrm{F}$ calculated value being 7.093 . Results show that the value of $\mathrm{F}$ arithmetic is larger than F table (7.093 > 2.17 ) with the significance level being less than 0.05 $(0.001<0.005)$. Therefore, it can be said that financial forward-looking information, reputation, leverage, size, trading volume, performance jointly affect stock volatility. Furthermore, the results of t-test of each independent variables on dependent variables can be explained as follows.

An adjusted $\mathrm{R}$ square of 0.391 indicates that the dependent variable's relationship with the independent and control variables can be explained by $32.9 \%$. The rest of the variance can be accounted for by factors not considered in this model. There is a substantial correlation between the dependent variable and all of the control variables (LEV, TVOL, SIZE, PERF) (STDRET). According to the t-value of -2.086 (>1.97882) and the Prob value of 0.042 , forward-looking information disclosure (FFLDIS) is statistically insignificant. A strong impact of financial forwardlooking information on stock volatility is accepted in H1.

There appears to be a negative correlation between stock volatility and the disclosure of forward-looking information in annual reports. The findings of this study are in line with those of a previous study by Bravo [2016], which found that asymmetric information, as proxied by stock volatility, is affected by future disclosures of information. Disclosing this information can help to minimize the information gap between firms and investors, which is consistent with agency theory.

REP's t-value is 0.554 and its Prob value is 0.582 (more than 0.05). Corporations' reputations appear to have an impact on sales, although it isn't as big as previously thought. Reputation has no major impact on stock volatility, which suggests that $\mathrm{H} 2$ is false.

Table 5. Double regression analysis

\begin{tabular}{|c|c|c|c|}
\hline Variable & Expected Sign & Coefficient & Probability \\
\hline \multicolumn{5}{|c|}{ Independent Variable } \\
\hline FFLDIS & - & -2.086 & $0.042^{* *}$ \\
\hline REP & - & 0.554 & 0.582 \\
\hline LEV & + & 2.797 & $0.007^{* *}$ \\
\hline SIZE & + & 2.334 & $0.024^{* *}$ \\
\hline PERF & - & -4.075 & $<0.001^{* *}$ \\
\hline
\end{tabular}

\begin{tabular}{|c|c|c|}
\hline TVOL & -2.574 & $0.013^{* *}$ \\
\hline R Square & 0.455 \\
\hline Adjusted R Square & \multicolumn{2}{|c|}{0.391} \\
\hline F (p-value) & $<0.001^{\text {** }}$ \\
\hline
\end{tabular}

Source : Author's Processed Results on SPSS Output

Investors may consider that information about reputation is no longer important during this period for any investment decision. In line with prior studies by [23], Although it is widely agreed that a company's reputation is an important aspect of its intangible assets, scholars and practitioners are unsure about its impact on stock value [2]. Also, [23] said that the portfolio of highly appreciated firms in a rising economy earns roughly $10 \%$ less than that market's general portfolio annually and discussed possible explanations for this finding.

\section{CONCLUSION}

When it comes to information disclosure, there are many different ways in which it can be made public. An important finding from this study is that disclosure, particularly financial forward-looking information, can reduce stock volatility, along with the company's size and financial leverage. Conversely, a company's reputation is not strong enough to diminish stock prices. This reinforces and validates earlier research on the changing nature of the economic environment.

For further research, it is suggested to do one with a different or multiple sectors with a larger sample size, and additional independent variables such as sales growth, cash ratio, and dividend pay-out ratio. It is also a good opportunity to continue this research into future years.

\section{REFERENCES}

[1] R. Darabi, "The effect of information asymmetry on stock return predictability," Res. J. Appl. Sci. Eng. Technol., pp. 929-936, 2013.

[2] F. Bravo, "Forward-looking disclosure and corporate reputation as mechanisms to reduce stock return volatility, Revista de Contabilidad," Spanish Account. Rev., vol. 19, no. 1, pp. 122131, 2015, doi: DOI: http://dx.doi.org/10.1016/j.rcsar.2015.03.001.

[3] E. Papaj-Wlisłocka and M. Strojek-Filus, "Forward-looking information disclosure as a risk factor in accounting - the case of Poland," Springer Proc. Bus. Econ., pp. 126-141, 2019, doi: DOI: https://doi.org/10.1007/978-3-03016045-6_5. 
[4] K. Aljifri and K. Husssainey, "The determinants of forward-looking information in annual reports of UAE companies," Manag. Audit. J., pp. 881-894, 2007, doi: DOI: https://doi.org/10.1108/02686900710829390.

[5] W. Utami, P. D. Wahyuni, and L. Nugroho, "Determinants of stock liquidity: forwardlooking information, corporate governance, and asymmetric information," J. Asian Financ. Econ. Bus., vol. 7, no. 12, pp. 795-807, 2020, doi:

DOI: https://doi.org/10.13106/jafeb.2020.vol7.no12.7 95.

[6] O. Celik, A. Ecer, and H. Karabacak, "Disclosure of forward-looking information: evidence from listed companies on Istanbul Stock Exchange [ISE]," Invest. Manag. Financ. Innov., vol. 3, no. 12, pp. 197-216, 2006.

[7] D. Cormier, M. J. Ledoux, M. Magnan, and W. Aerts, "Corporate governance and information asymmetry between managers and investors, Corporate Governance," Int. J. Bus. Soc., vol. 10, no. 5, pp. 574 - 589, 2010, doi: DOI: https://doi.org/10.1108/14720701011085553.

[8] C. Leuz and R. Verrecchia, "The economics consequences of increased disclosure," $J$. Account. Res., vol. 38, pp. 91-124, 2000, doi: DOI: https://doi.org/10.2307/2672910.

[9] K. Igawa and G. Kanatas, "Asymmetric information, collateral, and moral hazard," $J$. Financ. Quant. Anal., vol. 25, no. 4, pp. $469-$ 490, 1990, doi: DOI: https://doi.org/10.2307/2331011.

[10] B. J. Bushee and C. F. Noe, "Corporate disclosure practices, institutional investors, and stock return volatility," J. Account. Res., vol. 38, pp. 171-202, 2000, doi: DOI: http://dx.doi.org/10.2307/2672914.

[11] K. Alkhatib, "The determinants of forwardlooking information disclosure," Procedia - Soc. Behav. Sci., pp. 858 - 864, 2014, doi: DOI: https://doi.org/10.1016/j.sbspro.2013.12.554.

[12] K. Hussainey, M. Walker, and T. Schleicher, "Undertaking large-scale disclosure studies when AIMR-FAF ratings are not available: The case of prices leading earnings," Account. Bus. Res., pp. 275-294, 2003, doi: DOI: https://doi.org/10.1080/00014788.2003.9729654

[13] H. Handayani, H. Muharam, W. Mawardi, and R. Robiyanto, "Determinants of the stock price volatility in the Indonesian manufacturing sector," Int. Res. J. Bus. Stud., vol. 11, no. 3, pp. 179 - 193, 2019, doi: DOI: https://doi.org/10.21632/irjbs.
[14] K. A. Ganai, "An analysis of relationship between stock futures and underlying stock volatility," Arch. Bus. Res., vol. 8, no. 2, pp. 5164, 2020, doi: DOI: https://doi.org/10.14738/abr.82.7824.

[15] B. Sutrisno, "The determinants of stock price volatility in Indonesia," Econ. Account. J., vol. 3 , no. 1 , pp. $73-79$.

[16] S. Baek, S. K. Mohanty, and M. Glambosky, "COVID-19 and stock market volatility: An industry level analysis," Financ. Res. Lett., vol. 37, pp. 2-10, 2020, doi: DOI: https://doi.org/10.1016/j.frl.2020.101748.

[17] P. M. Healy and K. G. Palepu, "Information asymmetry, corporate disclosure, and the capital markets: A review of the empirical disclosure literature," J. Account. Econ., vol. 31, pp. $405-$ 440, 2001, doi: DOI: https://doi.org/10.1016/S0165-4101(01)000180 .

[18] A. Blajer-Gołębiewska, "Individual corporate reputation and perception of collective corporate reputation regarding stock market investments," PLoS One, vol. 16, no. 9, pp. 1-21, 2021, doi: DOI:

https://doi.org/10.1371/journal.pone.0257323.

[19] A. Blajer-Gołębiewska, "Corporate reputation and economic performance: the evidence from Poland," Econ. Sociol., vol. 7, no. 3, pp. 194207, 2014, doi: DOI: https://doi.org/10.14254/2071-789X.2014/7$3 / 15$.

[20] V. Pires and G. Trez, "Corporate reputation: A discussion on construct definition and measurement and its relation to performance," Rev. Gestão, vol. 25, no. 1, pp. 47-64, 2018, doi: DOI: https://doi.org/10.1108/REGE-112017-005.

[21] A. Blajer-Gołębiewska and A. Kozłowski, "Financial determinants of corporate reputation: A short-term approach," Manag. Econ., vol. 17, no. 2, pp. 179 - 201, 2016, doi: DOI: http://dx.doi.org/10.7494/manage.2016.17.2.179

[22] J. M. G. Lara, B. G. Osma, and F. Penalva, "Information consequences of accounting conservatism," Eur. Account. Rev., vol. 23, no. 2, pp. 173-198, 2014, doi: DOI https://doi.org/10.1080/09638180.2014.882263.

[23] O. Gök and H. Özkaya, "Does corporate reputation improve stock performance in an emerging economy? Evidence from Turkey," Corp. Reput. Rev., vol. 14, no. 1, pp. 53-61, 2011, doi: DOI: https://doi.org/10.1057/crr.2011.3. 